International Journal of Library \& Information Science (IJLIS)

Volume 8, Issue 3, September - December 2019, pp. 16-25, Article ID: IJLIS_08_03_003

Available online at

http://iaeme.com/Home/issue/IJLIS?Volume $=8 \&$ Issue $=3$

Journal Impact Factor (2019): 9.8614 (Calculated by GISI) www.jifactor.com

ISSN Print: 2277-3533 and ISSN Online: 2277-3584

(C) IAEME Publication

\title{
A SCIENTOMETRIC EVALUATION OF PUBLICATIONS IN STEM CELL REGENERATIVE MEDICINE JOURNALS AMONG GERMAN SOCIETY 2009 - 2018
}

\author{
Shilpa Kachru Tupe \\ Research Scholar, Dept. of Library \& Information Science, \\ Dr. Babasaheb Ambedkar Marathwada University, Aurangabad, India \\ Dr. Vaishali S. Khaparde \\ Professor and Head, Department of Library and Information Science, \\ Dr. Babasaheb Ambedkar Marathwada University, Aurangabad (MS), India
}

\begin{abstract}
Stem cells are self-renewing cells with the ability to differentiate into a variety of cells and are viewed to have great potential in the field of regenerative medicine. The study is based on the Scientometric evaluation of 159 publications published on Stem cell \& regenerative medicine Journals among German society during the period of 2009 -2018. The six scientometric tools Annual Growth Rate (AGR), collaborative index (CI), collaboration coefficient (CC), Degree of collaboration (DC), Relative Growth Rate ( RGR) and Doubling Time (DT) and Type of Documents have been used for the data analysis.
\end{abstract}

Key words: scientometrics, stem cell, regenerative medicine

Cite this Article: Shilpa Kachru Tupe and Vaishali S. Khaparde, A Scientometric Evaluation of Publications in Stem Cell Regenerative Medicine Journals Among German Society 2009 - 2018, International Journal of Library \& Information Science, 8(3), 2019, pp. 16-25.

$\mathrm{http}: / /$ iaeme.com/Home/issue/IJLIS?Volume $=8 \&$ Issue $=3$

\section{INTRODUCTION}

Stem cells have a capacity for self-renewal and capability of proliferation and differentiation to various cell lineages. They can be classified into embryonic stem cells (ESC) and nonembryonic stem cells (non-ESC). Mesenchymal stem cells (MSC) show great promise in several animal studies and clinical trials. ESCs have a great potential but their use is still limited due to ethical and scientific considerations. The use of amniotic fluid derived cells, umbilical cord cells, fat and skin tissues and monocytes might be an adequate "ethically pure" alternative in future. Stem cells can improve healthcare by using and augmenting the body's 
own regenerative potential. According to National institute of health (2016) Stem cells have the remarkable potential to develop into many different cell types in the body during early life and growth. In addition, in many tissues they serve as a sort of internal repair system, dividing essentially without limit to replenish other cells as long as the person or animal is still alive. When a stem cell divides, each new cell has the potential either to remain a stem cell or become another type of cell with a more specialized function, such as a muscle cell, a red blood cell, or a brain cell (para,1).

In the early 1900's European researchers realized that the various type of blood cells white blood cells, red blood cells and platelets all came from a particular 'stem cell'. Stem cells were first studied by Becker et al. (1963), who injected bone marrow cells into irradiated mice and noticed that nodules developed in the spleens of the mice in proportion to the number of bone marrow cells injected. They concluded that each nodule arose from a single marrow cell. Later on, they found by evidence that these cells were capable of infinite selfrenewal, a central characteristic of stem cells. Thus, stem cells by definition have two essential properties, i.e. the capacity of self renewal, and the capacity to differentiate into different cell lineages.

Regenerative medicine aims at helping the body to form new functional tissue to replace lost or defective ones. Hopefully, this will help to provide therapeutic treatment for conditions where current therapies are inadequate. Human body has an endogenous system of regeneration through stem cells, where stem cells are found almost in every type of tissue. The idea is that restoration of function is best accomplished by these cells. Regenerative medicine comprises the use of tissue engineering and stem cell technology. This review is not meant to be exhaustive, but aims to highlight present and future applications of stem cells in this exciting new discipline Bajada S et.al (2008).

\section{REVIEW OF LITERATURE}

Pandey A and Desai P. N. (2016) have carried out a scientometric analysis of stem cell research output for the year 1990-2014. Publication to exchange research findings is an important aspect of science and is one of the basis of methods to evaluate scientific productivity. A total of 3,24,175 papers were indexed in Scopus database during the year 1990-2014, out of which Indian authors contributed 3964 papers. Indian publication output increased from 8 papers in 1990 to 610 papers in 2014, witnessing an annual average growth rate of $18.93 \%$. Among different bibliographic forms, article is the dominant type $(74 \%)$, followed by reviews, latter, conference papers, etc. he mainstream of stem cell research is therapy, biochemistry, genetics, molecular biology, pharmaceutics, etc.

Daar and Greenwood (2007) stated that regenerative medicine aims at 'repair, replacement or regeneration of cells, tissue or organs to restore impaired function'. It aids the body to form new functional tissue to replace lost or defective tissue. Ultimately, this will help to provide therapeutic treatment for conditions where current therapies are inadequate. Cell therapy and tissue engineering are part of the broader field of regenerative medicine, whose aim is the delivery of safe, effective and consistent therapies. The human body has an endogenous system of regeneration and repair through stem cells, where stem cells can be found almost in every type of tissue. This process is highly evolved through evolution, and so it is logical that restoration of function is best accomplished by these cells. Therefore, stem cells hold great promise for the future of translational medicine (NRC, 2002).

Tupe S.K \& Khaparde V.S , (2016) The Present study deals a Scientometric analysis of 4813 references appended to 217 articles contributed by the authors in Information Technology and Libraries on DOAJ. during the period of 2005-2014. The study examines 
Authorship Pattern ,Relative Growth Rate and Doubling Time of Articles, Year wise degree of collaboration It is seen that the single authorship trend in increasing. The study revealed that most of the articles (57.14\%) of articles were contributed by single authors. USA is the top producing country with $178(82.03 \%)$ publications of the total output. The mean relative growth rate for the last five years 2010 to 2014 reduced to (0.13). While the Doubling time for different years [Dt(p)]gradually increased from (1.00) in 2006 to (7.70) in 2014. The mean doubling time for the first five years (i.e. 2005 to 2009) is only (1.69) which is increased to (5.69) during the last five years (2010 to 2014). The maximum references used print references i.e. 3154 whereas 1659 references were web references.

Velmurugan (2014) described the pattern of authorship and collaborative research on Indian Journal of Pure and Applied Physics for the year 2009 -2012. The study discussed the various factors such as year wise, author wise, volume wise, issue wise distribution of contributions during the period of study. The study used the scientometric indicators such as DC, RGR, and DT to measure the data.

\section{ABOUT THE JOURNAL}

The Journal of Stem cells and Regenerative Medicine (JSRM), an official organ of the German Society for Stem Cell Research (GSZ) is an Open access Online Journal covering areas of Basic Research, Translational work and Clinical studies in the specialty of Stem Cells and Regenerative Medicine including allied specialities such as Biomaterials and Nano technology relevant to the core subject. German Society for Stem Cell Research to Support the JSRM.JSRM published by G.N. Corporation Co. Ltd., Japan, since 1st of January, 2016. Earlier published by Nichi-Hepz Kenko (NHK) Services Pvt. Ltd, India, which now provides back office support for publication. The JSRM issues are published regularly and articles pertaining to Stem cells and Regenerative Medicine as well as related fields of research are considered for publications. This Online Journal conceived and run by Clinicians and Scientists, originally started for the student community with reputed members in the advisory/editorial boards, has now been accepted to be the official organ of GSZ is reaching millions of Researchers, Clinicians and Students all over the world.

\section{DEFINITIONAL ANALYSIS}

Scientometric - The term scientometrics came into being as a Russian term for the application of quantitative methods to the history of science (Dobrov \& Korennoi, 1969).Its scope and objectives have since broadened substantially. One can say that "Scientometrics" is a wide-ranging field encompassing bibliometerics. Scientometrics evolved out of a wide range of studies pertaining to the quantitative aspects of scientific endeavours, like, publications, journals, scatter of scientific literature, citation processes and patents, etc.

According to Nalimov and Mulchenko scientometrics is "a quantitative method of investigating the development of science as an information process" (Nalimov \& Mulchenko, 1969). In this information model, publications are carriers of information, journals are the channels of communication and bibliographical references symbolize the effect of prior research on the development of information flow.

Stem cells - Cells with the ability to divide for indefinite periods in culture and to give rise to specialized cells.

Regenerative medicine- A field of medicine devoted to treatments in which stem cells are induced to differentiate into the specific cell type required to repair damaged or destroyed cell populations or tissues. 
A Scientometric Evaluation of Publications in Stem Cell Regenerative Medicine Journals Among German Society $2009-2018$

\section{SCOPE \& LIMITATION OF THE STUDY}

The present study is based on the Scientometric evaluation of publications in stem cell regenerative medicine Journals among German society 2009 - 2018.

\section{DATA COLLECTION}

Data collected from the Journal of Stem cells and Regenerative Medicine for the period of 2009-2018 i.e. 10 years. A total number of 159 publications were received. The data was download and analyzed by using the Excel sheet. The data is used to find the annual growth rate and measures of DC, CI and CC in the journal of Stem cell \& regenerative medicine.

\section{OBJECTIVES OF THE STUDY}

- To find out Annual Publications output of Stem Cell \& Regenerative medicine.

- To estimate the annual growth rate (AGR) of publications.

- To measure the DC, and collaborative index (CI) of stem cell \& Regenerative medicine.

- To measure the Collaborative co-efficient of publications.

- To find out the form wise distribution of publications.

- To find out the Relative Growth Rate ( RGR ) and Doubling Time (DT) of publications.

\section{DATA ANALYSIS}

\section{Annual Publication output of Stem Cell \& Regenerative medicine}

\begin{tabular}{|c|c|c|c|c|c|}
\hline \multicolumn{7}{|c|}{ Table 1 } \\
\hline Sr. No & Year & No. of publication & \% & Cum. Records & Cum\% \\
\hline 1 & 2009 & 16 & 10.06 & 16 & 10.06 \\
\hline 2 & 2010 & 12 & 7.55 & 28 & 17.61 \\
\hline 3 & 2011 & 13 & 8.18 & 41 & 25.79 \\
\hline 4 & 2012 & 43 & 27.04 & 84 & 52.83 \\
\hline 5 & 2013 & 13 & 8.18 & 97 & 61.01 \\
\hline 6 & 2014 & 10 & 6.29 & 107 & 67.3 \\
\hline 7 & 2015 & 10 & 6.29 & 117 & 73.59 \\
\hline 8 & 2016 & 15 & 9.43 & 132 & 83.02 \\
\hline 9 & 2017 & 12 & 7.55 & 144 & 90.57 \\
\hline 10 & 2018 & 15 & 9.43 & 159 & 100 \\
\hline \multicolumn{7}{|c|}{ Total } & 159 & 100 & & \\
\hline
\end{tabular}




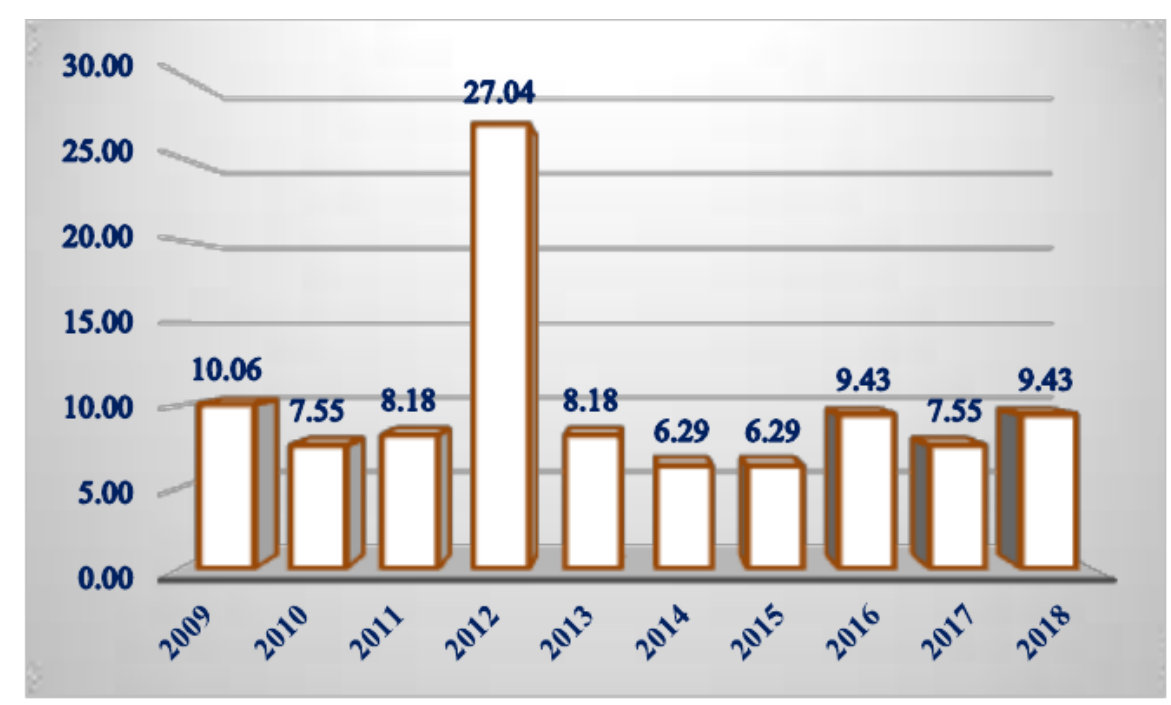

Figure 1 Annual Publication output of Stem Cell \& Regenerative medicine

As reflected in the total 159 publications were published in the journal of Stem Cells and Regenerative Medicine during the period 2009-2018. The cumulative output of stem cell and Regenerative Medicine increased from 107 publications during 2014 \& 159 papers 2018 showing a (Table 1).

\section{To estimate the annual growth rate (AGR) of publications}

\begin{tabular}{|c|c|c|c|}
\hline \multicolumn{5}{|c|}{$\begin{array}{c}\text { Table 2 } \\
\text { AGR of research publications }\end{array}$} \\
\hline Year & Volume & Total no. of publications & AGR \% \\
\hline 2009 & 5 & 16 & \\
\hline 2010 & 6 & 12 & -25 \\
\hline 2011 & 7 & 13 & 8.33 \\
\hline 2012 & 8 & 43 & 69.76 \\
\hline 2013 & 9 & 13 & -69.76 \\
\hline 2014 & 10 & 10 & -23.076 \\
\hline 2015 & 11 & 10 & -90 \\
\hline 2016 & 12 & 15 & 50 \\
\hline 2017 & 13 & 12 & -20 \\
\hline 2018 & 14 & 15 & 25 \\
\hline
\end{tabular}

The growth rate is a measurement which is essential in any field. In meaning the growth of the number of publications in a particular discipline, this is often a measure of the annual increase or decrease. Here, the AGR has been determined as per the formula given below.

$$
\begin{array}{rlr}
\text { AGR } & \frac{\text { End value }- \text { First }}{\text { Value }} & \times 100 \\
& \text { First Value } &
\end{array}
$$

In this study, the end value is 12 in the year 2009, the first value is 16 in the year .Table 2 shows that the year on the change in the number of documents was $-25 \%$ in $2010,8.33 \%$ over the respective next year. 
A Scientometric Evaluation of Publications in Stem Cell Regenerative Medicine Journals Among German Society $2009-2018$

\section{To measure the DC, and collaborative index (CI) of stem cell \& Regenerative medicine}

To show the trend towards multiple authorships in a discipline, many studies have used either the mean number of authors per paper, termed the CI by Lawani (1980) and the proportion of multiple authored papers, called Degree of Collaboration (DC) by Subramanyam (1983) as a measure of the strength of collaboration in a discipline.

\begin{tabular}{|c|c|c|c|c|}
\hline \multicolumn{5}{|c|}{$\begin{array}{c}\text { Table 3 } \\
\text { Degree of collaboration }\end{array}$} \\
\hline Year & Single authored & Multiple authored & Total & DC \\
\hline 2009 & 5 & 11 & 16 & 0.69 \\
\hline 2010 & 2 & 10 & 12 & 0.83 \\
\hline 2011 & 2 & 11 & 13 & 0.85 \\
\hline 2012 & 3 & 40 & 43 & 0.93 \\
\hline 2013 & 3 & 10 & 13 & 0.77 \\
\hline 2014 & 3 & 7 & 10 & 0.70 \\
\hline 2015 & 1 & 9 & 10 & 0.90 \\
\hline 2016 & 2 & 13 & 15 & 0.87 \\
\hline 2017 & 2 & 10 & 12 & 0.83 \\
\hline 2018 & 4 & 11 & 15 & 0.73 \\
\hline Total & 27 & 132 & 159 & 0.83 \\
\hline
\end{tabular}

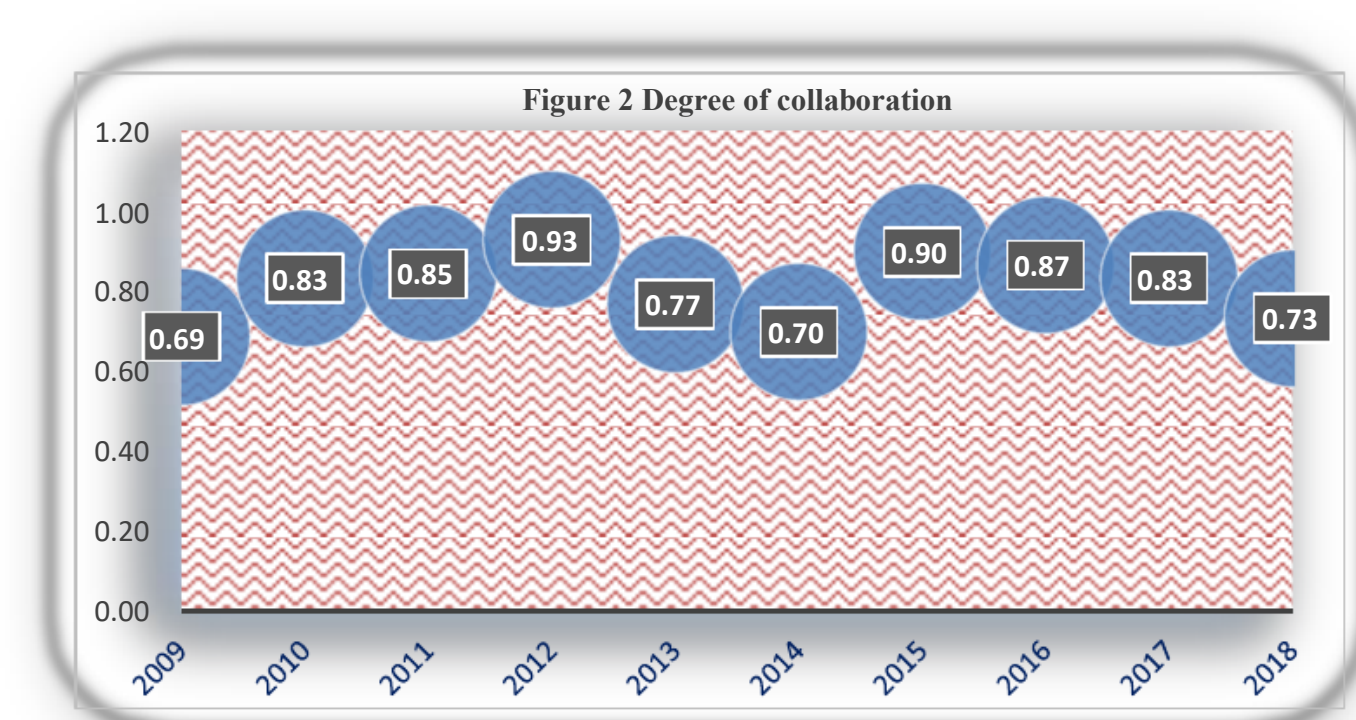

Table No. $3 \&$ Figure no. 2 shows that in the 10 years period, the multi authorship publications are higher and predominant than single authored. The multi authored articles are highest in the year 2012 with degree of collaboration (DC) was 0.93 . It is seen that the multi authorship trend in increasing. 


\begin{tabular}{|c|c|c|c|c|c|c|}
\hline \multicolumn{7}{|c|}{ Collaborative index in stem cell \& Regenerative medicine } \\
\hline Year & Single Author & Two Author & Three Author & > Four Author & Total & CI \\
\hline 2009 & 5 & 2 & 2 & 7 & 16 & 2.69 \\
\hline 2010 & 2 & 2 & 1 & 7 & 12 & 2.92 \\
\hline 2011 & 2 & 1 & 1 & 9 & 13 & 3.08 \\
\hline 2012 & 3 & 1 & 4 & 35 & 43 & 3.63 \\
\hline 2013 & 3 & 2 & 2 & 6 & 13 & 2.85 \\
\hline 2014 & 3 & 1 & 1 & 5 & 10 & 2.50 \\
\hline 2015 & 1 & 1 & 1 & 7 & 10 & 3.10 \\
\hline 2016 & 2 & 4 & 1 & 8 & 15 & 2.87 \\
\hline 2017 & 2 & 1 & 3 & 6 & 12 & 3.00 \\
\hline 2018 & 4 & 2 & 2 & 7 & 15 & 2.80 \\
\hline Total & 27 & 17 & 18 & 97 & 159 & 3.16 \\
\hline
\end{tabular}

Collaborative Index

$$
\mathrm{CI}=\frac{\sum A \mathrm{~A}=1 \mathrm{jfi}}{\mathrm{N}}
$$

Collaborative Index provides the year wise mean number of authors per multi authored paper. CI ranges from 2.50 (2014) to 3.63 (2013) with an average of 3.16 per multi authored paper.

\section{To measure the Collaborative co-efficient of publications}

According to Ajiferuke et al.(1988) who have shown the mean number of authors per paper, the proportion of multiple authorship as a measure of degree of collaboration in a discipline, is inadequate. Therefore, they have proposed a measure combining some of the merits of both measures into what is known as Collaborative Coefficient.

Suppose, if a paper has a single author, the author receives one credit; if two, each receives $1 / 2$ credits. In general, if we have ' $n$ ' authors each receive $1 / n$ credits. Hence, the average credit awarded to each author of a random paper is $E[1 / n]$, a value which lies between 0 and 1 . If ' 0 ' is to correspond to single authorship, then the $\mathrm{CC}$ is defined as:

$$
\begin{aligned}
\mathrm{CC} & =1-\mathrm{E}[1 / \mathrm{n}] \\
& =1-(1 / \mathrm{j}) \mathrm{p}(\mathrm{N}=\mathrm{j})
\end{aligned}
$$

And its $\operatorname{sum} \sum$ rate $=1-\mathrm{f} 1+(1 / 2) \mathrm{f} 2+(1 / 2) \mathrm{f} 3+\ldots(1 / \mathrm{k}) \mathrm{fk} \quad \mathrm{N}$

Based on the data in the Table 4.

$$
\begin{aligned}
\mathrm{CC} & =1-[\mathrm{f} 1+(1 / 2) \mathrm{f} 2+(1 / 3) \mathrm{f} 3+\ldots+(1 / \mathrm{k}) \mathrm{fk}] / \mathrm{N} \\
\mathrm{CC} & =1-\{[5+(1 / 2) 2+(1 / 3) 2+(1 / 4) 7] / 16 / \mathrm{N}\} \\
& =1-\{[5+1+0.66+1.75] / 16\} \\
& =1-[8.41 / 16] \\
& =1-0.5256 \\
& =0.4744
\end{aligned}
$$


A Scientometric Evaluation of Publications in Stem Cell Regenerative Medicine Journals Among German Society $2009-2018$

\begin{tabular}{|c|c|c|c|c|c|c|}
\hline \multicolumn{7}{|c|}{ Collaborative co-efficient in stem cell \& Regenerative medicine } \\
\hline Year & Single Author & Two Author & Three Author & > Four Author & Total & CC \\
\hline 2009 & 5 & 2 & 2 & 7 & 16 & 0.47 \\
\hline 2010 & 2 & 2 & 1 & 7 & 12 & 0.58 \\
\hline 2011 & 2 & 1 & 1 & 9 & 13 & 0.61 \\
\hline 2012 & 3 & 1 & 4 & 35 & 43 & 0.68 \\
\hline 2013 & 3 & 2 & 2 & 6 & 13 & 0.58 \\
\hline 2014 & 3 & 1 & 1 & 5 & 10 & 0.49 \\
\hline 2015 & 1 & 1 & 1 & 7 & 10 & 0.64 \\
\hline 2016 & 2 & 4 & 1 & 8 & 15 & 0.58 \\
\hline 2017 & 2 & 1 & 3 & 6 & 12 & 0.56 \\
\hline 2018 & 4 & 2 & 2 & 7 & 15 & 0.51 \\
\hline Total & $27(16.98)$ & $17(10.69)$ & $18(11.32)$ & $97(61.00)$ & 159 & 0.59 \\
\hline
\end{tabular}

Table 4 shows that the CC has increased from 0.47 in 2009 to 0.51 in 2018 indicating that research among analyst is fairly collaborative with an average CC of 0.58 .

\section{To find out the form wise distribution of publications}

\begin{tabular}{|c|c|c|c|}
\hline \multicolumn{5}{|c|}{ Form wise Distribution of Publications } \\
\hline Sr.No & Type of Documents & Publications & \% \\
\hline 1 & Proceedings & 56 & 35.22 \\
\hline 2 & Research Articles & 29 & 18.24 \\
\hline 3 & Review Articles & 25 & 15.72 \\
\hline 4 & Editorial & 19 & 11.94 \\
\hline 5 & Original Articles & 17 & 10.69 \\
\hline 6 & Brief Communication & 6 & 3.77 \\
\hline 7 & Letter of the Editor & 2 & 1.26 \\
\hline 8 & Opinion Article & 2 & 1.26 \\
\hline 9 & Book Review & 1 & 0.63 \\
\hline 10 & Case Report & 1 & 0.63 \\
\hline 11 & NA & 1 & 0.63 \\
\hline \multicolumn{7}{|c|}{} & 159 & 100 \\
\hline
\end{tabular}

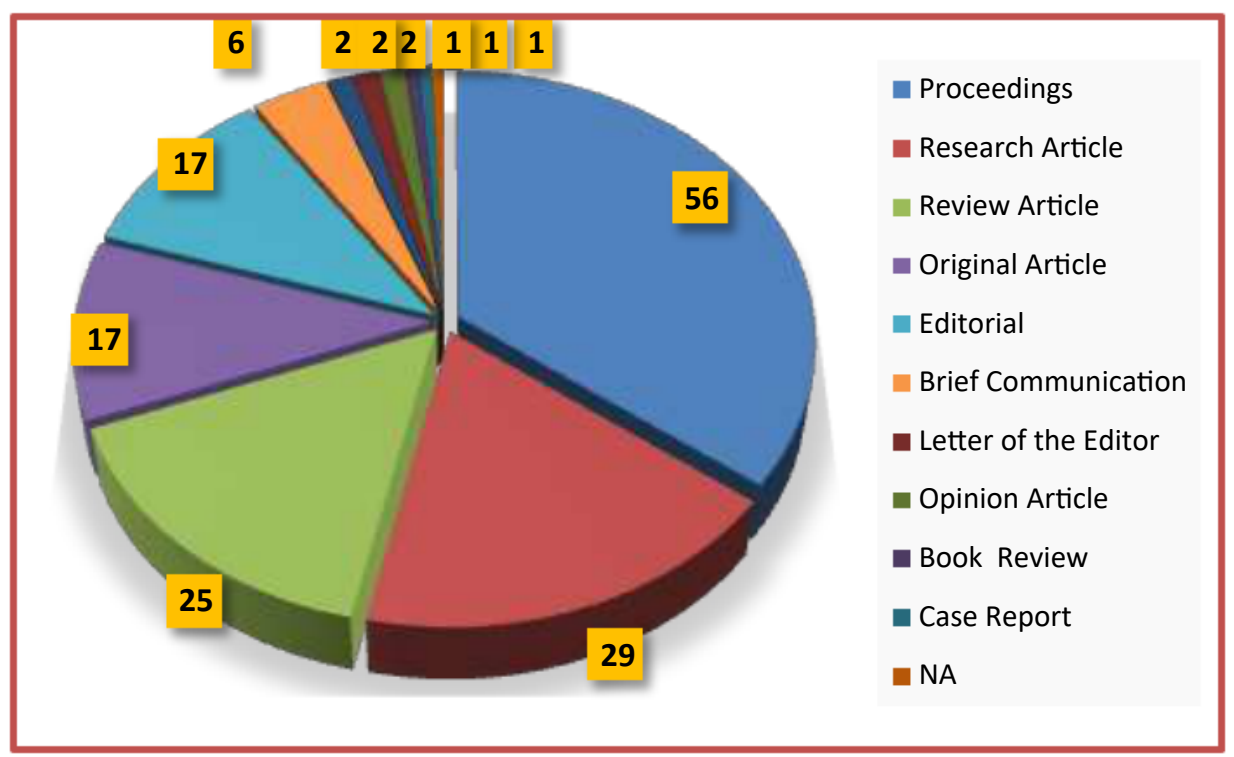

Figure 3 Form wise Distribution of Publications 
Table No. 5 \& Figure no. 3 gives the publications were divided in to 10 document types, the form wise distribution of publications out of the total 159 publications, 56 (35.22\%) publications were in Proceedings form. Followed by other document type such as Research Article 29 (18.24\%) Review Article $25(15.72 \%)$, Original Article \&Editorial 19 with (11.94\%) respectively.

\section{To find out the Relative Growth Rate ( RGR ) and Doubling Time (DT) of publications}

\begin{tabular}{|c|c|c|c|c|c|c|c|c|}
\hline & & Relative Gro & Rate & $\begin{array}{l}\text { Tabl } \\
\text { Doub }\end{array}$ & g Tim & of publicatio & & \\
\hline Year & $\begin{array}{l}\text { No. of } \\
\text { Pub }\end{array}$ & $\begin{array}{l}\text { Cumulative } \\
\text { Frequency }\end{array}$ & W1 & W2 & RGR & $\operatorname{Mean}[R(A)]$ & DT(A) & $\begin{array}{l}\text { Mean } \\
\text { DT(A) }\end{array}$ \\
\hline 2009 & 16 & 16 & & 2.77 & & \multirow{5}{*}{0.36} & & \multirow{5}{*}{1.79} \\
\hline 2010 & 12 & 28 & 2.77 & 3.33 & 0.56 & & 1.24 & \\
\hline 2011 & 13 & 41 & 3.33 & 3.71 & 0.38 & & 1.82 & \\
\hline 2012 & 43 & 84 & 3.71 & 4.43 & 0.72 & & 0.96 & \\
\hline 2013 & 13 & 97 & 4.43 & 4.57 & 0.14 & & 4.95 & \\
\hline 2014 & 10 & 107 & 4.57 & 4.67 & 0.10 & \multirow{5}{*}{0.1} & 6.93 & \multirow{5}{*}{7.01} \\
\hline 2015 & 10 & 117 & 4.67 & 4.76 & 0.09 & & 7.70 & \\
\hline 2016 & 15 & 132 & 4.76 & 4.88 & 0.12 & & 5.77 & \\
\hline 2017 & 12 & 144 & 4.88 & 4.97 & 0.09 & & 7.70 & \\
\hline 2018 & 15 & 159 & 4.97 & 5.07 & 0.10 & & 6.93 & \\
\hline
\end{tabular}

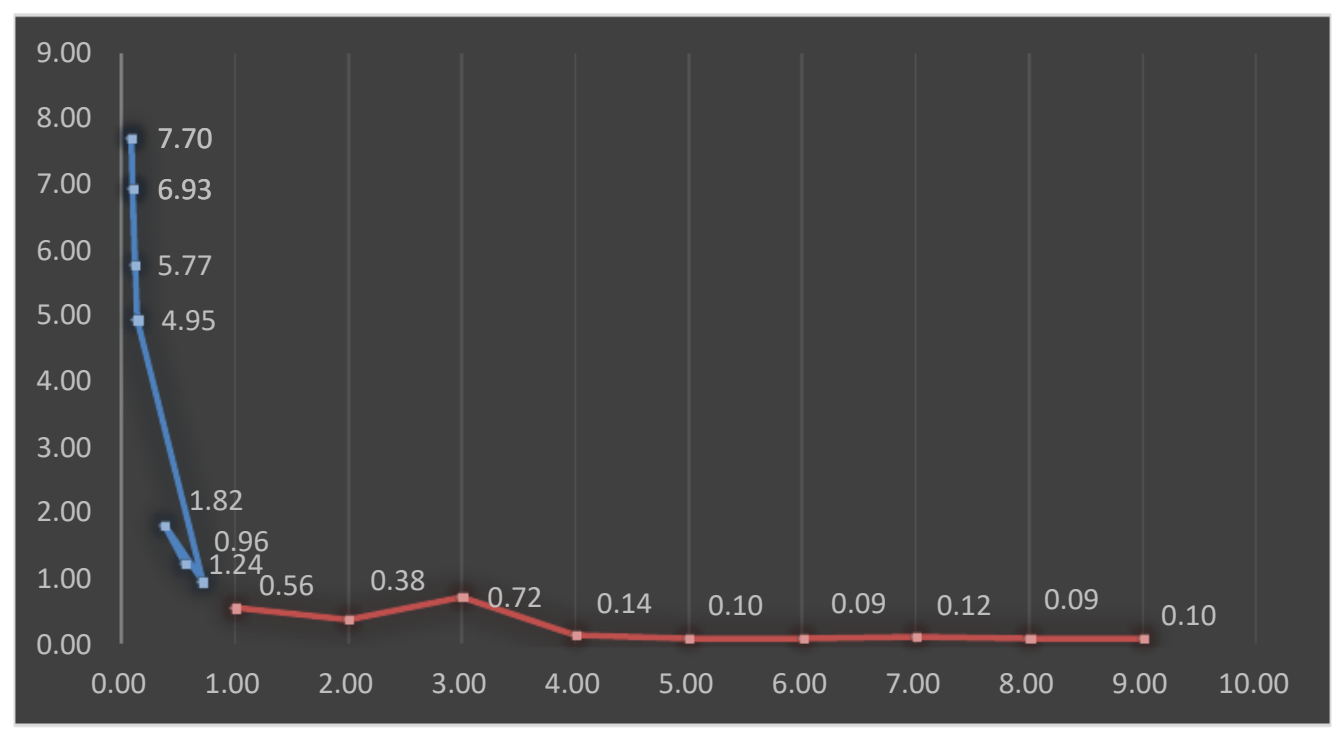

Figure 4 Relative Growth Rate \& Doubling Timing of publications

Table No.06 \& Figure no.4 It noticed that the mean relative growth for the first five years 2009 to 2013 is (0.36), and the mean relative growth rate for the last five years 2014 to 2018 reduced to $(0.1)$. While the Doubling time for different years [Dt $(\mathrm{p})$ ] gradually increased from (7.70) in $2015 \& 2017$. The mean doubling time for the first five years (i.e. 2009 to 2013) is only (1.79) which is increased to (7.01) during the last five years (2014 to 2018). Thus as the rate of growth of publications was decreased, the corresponding Doubling Time was increased. 
A Scientometric Evaluation of Publications in Stem Cell Regenerative Medicine Journals Among German Society $2009-2018$

\section{FINDINGS \&CONCLUSION}

The potential of stem cell to change the face of medical treatment has brought it to the forefront of medical science in recent years. It is observed in the present study that, the number of publications in stem cell regenerative medicine Journals among German society 2009 - 2018 has 159 publications in ten years. multi authorship publications are higher and predominant than single authored. The multi authored articles are highest in the year 2012 with degree of collaboration (DC) was 0.93 and the average of CC of 0.58. The highest publication of proceeding form. The Collaborative Index varies from 2.50 in 2014 with highest collaboration of 3.63in 2013.

\section{REFERENCES}

[1] Ajiferuke et.al (1988). Collaborative coefficient: A single measure of the collaboration in research. Scientometrics, 14, 421-433.

[2] Becker, A.J., McCulloch, E.A., Till, J.E. (1963). Cytological demonstration of the clonal nature of spleen colonies derived from transplanted mouse marrow cells. Nature, 197, $452-454$.

[3] Bajada S et.al (2008) . Stem Cells in Regenerative Medicine. https://www.oulu.fi/spareparts/ebook.

[4] Daar, A.S., Greenwood, H.L. (2007). A proposed definition of regenerative medicine. J. TissueEng. Regen. Med., 1, 179-184.

[5] Dobrov,G.M.,\&Korennoi,A.A (1969).The informational basis of scientometrics. On the theoretical problems of informetrics, VINITI for FID, 165-191.

[6] Lawani, S. M. (1980). Quality, collaboration and citations in cancer research: A 268 bibliometric study. Ph.D. Dissertation, Florida State University, 395 pp.

[7] Nalimov,V.V., \& Mulchenko,Z.M.(1969). Naukometriya Izucheniye Razvitiya nauki kak Informatsionnogo protsessat.

[8] National Institutes of Health, (2016). Stem cell information. Retrieved on 30 July 2019, from $</ /$ stemcells.nih.gov/info/basics/1.htm $>$

[9] NRC (National Research Council) (2002). Stem Cells and the Future of Regenerative Medicine Committee on the Biological and Biomedical Applications of Stem Cell

Research, Board on Life Sciences, National Research Council, Board on Neuroscience and Behavioral Health, Institute of Medicine. ISBN: 0-309-50974-2, 112 pages,

NATIONAL ACADEMY PRESS, Washington, D.C.

http://www.nap.edu/catalog/10195.html

[10] Pandey A and Desai P. N. (2016). Emerging Structure of Stem Cell Research in India: An Analysis of Publication Output, 1990-2014. J Scientometric Res.5 (1):59-61.

[11] Tupe, S. K. , \& Khaparde V. S (2016) . Scientometric study on journal of information technology \& librarieson DOAJ. "Knowledge Librarian" An International Peer Reviewed Bilingual E-Journal of Library and Information Science,3(3), 10-26.

[12] Velmurugan C.(2014). Research trends in Indian Journal of Pure and Applied Physics (IJPAP) for the year 2009-2012. Asian Rev Soc Sci.3:24-8. 